\title{
The Determinants of Inequality and Income Gap between Urban and Rural Areas in Cameroon: Evidence from the ECAM3 Household Survey
}

\author{
Samuel Fambon \\ Faculty of Economic and Management, University of Yaoundé II, Cameroon
}

Copyright $(2017$ by authors, all rights reserved. Authors agree that this article remains permanently open access under the terms of the Creative Commons Attribution License 4.0 International License

\begin{abstract}
This paper analyzes the determinants of income and the urban-rural income gap to highlight the urban-rural inequality problem in Cameroon. It concurrently uses the OLS regression, the conditional quantile regression as well as the Blinder-Oaxaca decomposition techniques to achieve this objective. The findings of OLS estimations show that human resources and social as well as physical capital play a major role in the improvement of welfare. Household size reduces the consumption expenditures both in rural and urban areas. The regions where the households reside also affect consumption expenditures. Household heads who work in the services sector and trade are better-off than those working in the other sectors of the economy. However, quantile regressions results show that households headed by the old people enjoy a higher level of welfare in the upper quintiles of the distribution of consumption. Household heads who work in the industrial sector have a negative relationship with consumption at the $10^{\text {th }}$ quintile of the distribution of household expenditures in the urban area. In the rural area, household heads working in the services sector have a positive relationship with consumption only at the $50^{\text {th }}$ and $90^{\text {th }}$ percentiles of the distribution of expenditures, whereas those belonging to the $10^{\text {th }}$ quintile have a negative relationship with consumption. In the rural area, the average time span spent to reach an asphalted road has a stronger positive impact on the consumption of households belonging to the $90^{\text {th }}$ percentile of the distribution of expenditures. Being a member of an association has a significant positive effect only on the consumption of households belonging to the $10^{\text {th }}$ quintile of the expenditures distribution. The study results derived with the help of the Oaxaca-Blinder decomposition method show that 59 percent of the welfare gap between urban and rural areas may be explained by differences in the characteristics, and most particularly in physical assets and education. The remaining 41 percent of the welfare gap is explained by discrimination.
\end{abstract}

JEL Classification: O15, O18, D31, D63, O55

Keywords Inequality, Urban-rural Income Gap,
Oaxaca-blinder Decomposition, OLS, Quantile Regressions, Cameroon

\section{Introduction}

In developing countries, the link between urban and rural sectors is characterized by the economic dualism which manifests itself through the coexistence of a modern urban sector and a traditional rural sector. This dualism has facilitated the isolated resolution of problems that affects each area. The main premise is that the lack of urban-rural optimal links is bad for the enlarged growth of the economy, for it divides societies and leads to inefficiencies, a situation which is an original cause of inequality that in itself inhibits growth [1].

In recent years, regional inequality has become both for researchers and decision makers, an important policy problem to reduce global inequality in several developing countries, owing to its social and economic implications. Several studies are focused on living standards across regions such as the factors which contribute to the urban-rural income gap. In Sub-Saharan Africa, a region which is considered as among the most unequal in the world ${ }^{1}$, the analysis of regional inequality has received little attention in the previous literature. Given these factors, the study of the differences in urban and rural incomes is crucial to understanding regional development models [3].

The objective of this paper is therefore to examine the determinants of income and the urban-rural income gap to clarify the urban-rural inequality problem in Cameroon.

We achieve the objectives of the study by analyzing the determinants of household income to find out how these

1 In addition to being of the poorest regions in the world, Africa is also the world's second most inequitable region after Latin America. Inequalities have not diminished over time. In 2010, six out of the 10 most unequal countries worldwide were in Sub-Saharan Africa [2]. 
factors contribute to the income gap. The analysis has been conducted according to the following steps: firstly, we use the classical ordinary least squares (OLS) regression method to estimate the logarithmic equation of household income. Even if the quantitative malleability on the computer of the OLS estimator is attractive, it cannot reveal the effects of independent variables on the «form» of the income distribution. Secondly, to resolve this problem, we apply the conditional quantile regression proposed by Koenker and Bassett [4]. Contrary to the least squares (OLS) regression technique, the quantile regression method provides corresponding regression curves to diverse points of the income distribution. Lastly, we use the Blinder-Oaxaca decomposition method to explore the extent to which the urban-rural income gap may be explained by the individual characteristics of household heads and the community characteristics.

The paper is organized as follows. After the introduction in Section 1, Section 2 reviews and summarizes the relevant literature concerning studies on income inequality in Cameroon. In Section 3, we present the methodology of the study. Section 4 presents the data and the variables used in the study. Section 5 analyzes the results, and Section 6 summarizes the main results of the study and their policy implications.

\section{Literature Review}

Several measures have been proposed in the literature to characterize inequality in the distribution of income or expenditure [5-10] and [11]. One of the inequality measures of interest is the one proposed by Fields [12] which makes it possible to evaluate the importance of the specific attributes of the household in the explanation of the level of inequality, where the amount explained by each factor is independent of the inequality measure used. This method consists in carrying out a set of regressions. The alternative approach is the quantile regression method in which, instead of estimating the mean of a conditional dependent variable using the values of independent variables, we estimate the median, that is, we minimize the sum of absolute residuals instead of the sum of squared residuals as in ordinary least squares regressions. It is possible to estimate different percentiles of dependent variables, and thus to obtain the estimates of different parts of the income or expenditure distribution [13].

There exist a number of studies on income inequality in Cameroon which have applied one or the other of the inequality measures mentioned above. For instance, Chameni Nembua, C. and Miamo Wendji, C., [14] have analyzed consumption expenditure inequality in Cameroon over the period 1996-2007, using the Shapley-Shorrocks method of decomposing inequality into population sub-groups and by income/expenditure sources. Their results show that food and housing expenditures explain inequality according to income sources, while the expenditure distribution is more unequal among men household heads in the urban area and among those aged 31 and 50 in the case of decomposition into sub-groups of the population.

Epo and Baye [15] applied the inequality decomposition approach based on regression to explore the determinants of income inequality in Cameroon, using the 2007-Cameroonian household survey data. Their results show that the income sources attributable to education, health, urban residence, household size, the proportion of active household members, formal sector workers and ownership of agricultural land, are the main determinants of household income inequality in that order in Cameroon.

Fambon [16] examined the evolution of inequality in the distribution of income in Cameroon between 1984 and 1996 by breaking inequality down into within- and between-groups inequality components, using the Gini coefficient decomposition method based on Shapely-value and total expenditure per adult equivalent as welfare indicator to determine the contributions of these inequality components to total inequality at the national level. The decomposition is carried out according to areas, strata, educational level, gender, and the household head age group. The results of this study show that total expenditure inequality fell slightly between 1984 and 1996, and that the contributions of within-groups inequality components to total inequality for the five socio-economic characteristics mentioned above, predominantly explain total inequality at the national level in Cameroon.

Baye and Fambon [17] examined the characteristics of inequality in Cameroon and carried out its decomposition with the help of the generalized entropy class of inequality indices, using the 1996-Cameroonian household survey data gathered by the National Bureau of Statistics of Cameroon. The results of this study show that inequality is more pronounced in the urban area and among the more educated, households headed by women, households whose heads are young, as well as among formal sector employees and qualified employers. Inequality is explained predominantly by the within-groups inequality components while the between-groups inequality contributions to total inequality are marginal in some cases and negligible in others.

Let us note in passing that the aforementioned studies did not analyze the determinants of income inequality using the quantile regression method. Moreover, none of these studies did analyze the urban-rural income gap in Cameroon.

The majority of empirical studies that analyze the urban-rural income gap in developing countries have focused either on the cursory measures of the distribution of income or they have decomposed the urban-rural income gap using generally the Oaxaca-Blinder decomposition method. For instance, Sicular, Yue, Gustafsson and Li [18] analyzed the urban-rural income gap in China, its share contribution to inequality and the factors responsible of the gap, using the data derived from the household surveys of the years 1995 and 2002. They examined income inequality in the urban and rural areas for different groups of the population using the Oaxaca-Blinder decomposition method, and found that education was the only characteristic whose contribution to 
the income gap was significant between the urban and rural areas.

$\mathrm{Su}$ and Heshmati [19] examined the determinants of income and the urban-rural income gap in China using the ordinary least squares (OLS) regression, the conditional quantile regression and the Blinder-Oaxaca decomposition methods, in addition to the four waves of the China Health and Nutrition Survey (CHNS) household data. The results of this study show that education and occupation are the key determinants of the income level of the household. Both of these factors exert heterogeneous effects at different percentiles of the income distribution. In the urban area, education has more value for those who have high incomes, whereas in rural areas, specialized or tertiary education is more beneficial for the poorest households. Among all types of occupations, agricultural activities have shown lower returns than other types of activities; and this is more evident for individuals lying at the left tail of the income distribution. The authors also found that for the provinces sampled, the urban-rural income gap increased from 2000 to 2004 and decreased from 2004 to 2009 . The income gap may be largely explained by individual attributes, and mainly by the educational level and the type of occupation.

Ali et al. [20] examined the determinants of income and the income gap in the urban and rural areas of Pakistan using the province, the literacy rate, education, occupation, age, gender and the matrimonial status as predictors at the individual level using the Household Integrated Economic Survey (HIES) 2010-11 dataset. The traditional model of Mincer is estimated by applying the OLS regression method. The Blinder-Oaxaca decomposition method was also used to analyze the income gap between urban and rural Pakistan. The results show that the schooling level, education and occupation are the main determinants of income in Pakistan. The ability of individuals to read and to write also emerged as being more important than the ability to calculate. Low levels of education provide high returns in the rural area, whereas high levels of education yield more returns in the urban area. Agricultural workers and fishermen emerged from the study as the least salaried workers followed by those engaged in the least paid elementary occupations. Individual characteristics such as the schooling level, education, occupation and matrimonial status were found to be the key determinants of the income gap.

Some recent studies have adopted a more detailed approach and have decomposed the urban-rural income gap by focusing on the entire (specific) distribution of income and not just on the means.

Nguyen et al. [21] used the quantile regression method to analyze urban-rural consumption expenditure inequality in Vietnam in 1993 and 1998. The authors found that the income gap in 1993 was mainly explained by differences in the co-variables, while in 1998 the income gap was due to differences in the returns across regions, and for both years, the returns due to the co-variables were larger at the top of the distribution of household consumption expenditure per capita. Similarly, Shilpi [22] and Chamarbagwala [23] in the respective cases of Bangladesh and India, adopted the quantile decomposition method to analyze urban-rural income inequality. These studies found evidence suggesting that both the co-variables and the returns were relevant in explaining the observed income gap, although their behaviours were different across the distribution of welfare.

Matita and Chirwa [24] analyzed the extent of urban-rural welfare inequalities in Malawi with the help of a representative sample at the national level as well as the factors which contribute to such inequalities, using the decomposition techniques of both Oaxaca-Blinder [25, 26] and Machado and Mata [27] The decomposition results of this study notably show that a large share of the welfare gap may be explained by the differences in the characteristics «physical assets and education» rather than by discrimination.

All in all, there emerges from this brief review of the literature an absence of studies dealing with the analysis of urban-rural income inequality in Cameroon. Under these conditions, and based on the literature, this study analyzes income inequality and the income gap between the urban and rural areas of the country by using OLS and quantile regressions and the Oaxaca-Blinder decomposition method. The analysis will be conducted from the aspects of individual and community characteristics, by trying to determine how the age of a person, his or her level of education, occupation, matrimonial status, etc., respectively affect the income levels of rural and urban residents, and how these factors contribute to the income gap. Moreover, we use data derived from the 2007-Cameroonian household survey (ECAM3) which consequently will make it possible for us to provide the most recent information on the state of urban-rural income inequality in Cameroon.

\section{Methodology}

To estimate the effects of household and community characteristics on urban and rural annual household expenditures, we use both the ordinary least squares (OLS) regression and the quantile regression methods.

The standard OLS model is written as follows:

$$
\operatorname{Ln}\left(y_{i}\right)=\beta X_{i}+\varepsilon_{i}
$$

where, $\operatorname{Ln}\left(y_{i}\right)$ is the natural logarithm of the total annual expenditure per adult equivalent of household $i ; X_{i}$ is the vector of the individual characteristics of the household and of the community; $\beta$ is a vector of unknown parameters to be estimated, and $\varepsilon_{i}$ is the random disturbance term which is assumed to satisfy the usual properties of zero mean and constant variance.

The OLS regression method assumes that the effects of regressors do not vary along the conditional distribution of the dependent variable. For example, the effect of schooling on household welfare is assumed to be the same at the bottom as well as at the top of the welfare distribution. However, if these effects vary along the household welfare 
distribution, quantile regressions, which provide models for different percentiles of the welfare distribution, constitute a parsimonious way to describe the whole distribution.

The classical linear regression is an estimation method of the conditional average functions by minimizing the sum of squared residuals. Similarly, in the conditional quantile regression we use an optimization of the linear objective function of residuals. We specify Equation (1) in the form of the quantile regression as follows:

$$
Q_{\tau} \ln \left(y_{i} / X_{i}\right)=X_{i}^{\prime} \beta_{\tau}+\varepsilon_{i, \tau}
$$

where $Q_{\tau} \ln \left(y_{i} / X_{i}\right)$ is suggesting to estimate the $\log$ of total expenditure per adult equivalent model at $\tau-t$ th quantile $\left(Q_{\tau}\right)$ of the distribution of the dependent variable $(Y)$ conditional on the value of $X$. Following Koenker, R. and Bassett,G., Jr [4] , the income of an individual is in the $\tau-t h$ quantile if his income is higher than the proportion $\tau$ of the reference group of individuals and lowers than the proportion $(1-\tau) \beta_{\tau}$ is the estimated parameter for each explanatory variable correspondingly. Other notations remain the same meaning as they are indicated in equation (1).

Assuming that the $r$-th quantile of error term conditional on the regressors is zero $\left(Q_{\tau}\left(u_{i, \tau} / x_{i}=0\right)\right)$, then the $r$-th conditional quantile of $y_{i}$ with respect to $x_{i}$ can be written as:

$$
Q_{\tau}\left(y_{i} / x_{i}\right)=x_{i}^{\prime} \beta_{\tau}
$$

Using median regression method, also known as the sum of absolute deviation (LAD) estimator, we minimize the sum of absolute residuals with symmetrical and asymmetrical weighting systems. The parameter vector $\beta_{\tau}$ can be estimated by:

$$
\begin{aligned}
& \hat{\beta}_{\tau}=\arg \min \left\{\begin{array}{l}
\sum \tau\left|y_{i}-\left(x_{i}^{\prime} \beta_{\tau}\right)\right|+\sum(1-\tau)\left|y_{i}-\left(x_{i}^{\prime} \beta_{\tau}\right)\right| \\
i \in\left\{? / y_{i} \geq x_{i}^{\prime} \beta_{\tau}\right\}
\end{array}\right\} \\
& \beta_{\tau} \in R^{k} \\
& =\arg \min \sum \rho_{\tau}\left(y_{i}-\xi\left(x_{i}, \beta_{\tau}\right)\right) \\
& \beta_{\tau} \in R^{k}
\end{aligned}
$$

Where, the function $\rho_{\tau}($.$) is the absolute value function$ which provides the sample of quantile $\tau-t h$ and $\xi\left(x_{i}, \beta\right)$ is the linear function of parameters. In this paper, we estimate the model at the median or at the $50^{\text {th }}$ percentile, as well as at the $10^{\text {th }}$ and the $90^{\text {th }}$ percentiles of the distribution of consumption expenditures. We can then determine whether the position of quantiles in the distribution of consumption expenditures differently affects the manner in which household characteristics are linked to consumption. This differentiation across households is important for the analysis and the formulation of distributional policies which may alter consumption models across households.

The second step of our analysis is an investigation of the factors which explain the urban-rural income gap. In this respect, we use the method of decomposition of Oaxaca-Blinder which provides information on the extent to which the gap reflects the differences between the urban and rural area in the characteristics of households and community, in contrast to the simple residence site. This method also provides, though in the partial equilibrium perspective, the size the gap would have if rural and urban groups had similar characteristics. Such information is useful in a policy perspective. For example, if the differences in educational characteristics between the rural and urban areas contribute substantially to the urban-rural income gap, then the decision makers could focus their attention on the determinants and consequences of the educational levels in both areas.

The classical Oaxaca-Blinder decomposition method breaks down the average welfare gap between two groups into two components at a point in time: the first component represents the differences in endowments between two groups, while the second component represents the differences in the results of these endowments. More formally, the estimated welfare ratio gap may be broken down as follows:

$$
\overline{\ln y^{\text {urban }}}-\overline{\ln y^{\text {rural }}}=\left(\overline{X^{\text {urban }}}-\overline{X^{\text {rural }}}\right) \beta^{\text {urban }}+\left(\beta^{\text {urban }}-\beta^{\text {rural }}\right) \overline{X^{\text {urban }}}
$$

where, $\ln y$ is a measure of the welfare ratio of the household; $X$ is the a vector of the characteristics of the $\mathrm{i}^{\text {th }}$ household; $\beta$ is a vector of coefficients. The bars over the $X$ vectors denote the mean of characteristics and the bars over the $\ln y^{\prime} s$ represent the mean of the logarithm of the household's welfare ratio.

Equation five above implies the fact that the differential in the average welfare ratios between the urban and rural areas may be decomposed into two components: a component made up of the differences in the average characteristics summarized by the term $\left(\overline{X^{\text {urban }}}-\overline{X^{\text {rural }}}\right)$, and another component which is due to the differences in the coefficients or results of the characteristics in the urban and rural areas, summarized by the term $\left(\beta^{\text {urban }}-\beta^{\text {rural }}\right)$.

\section{The Data and the Variables Used}

\subsection{The Data}

The data used in this study come from the Cameroonian household survey ECAM3 which is representative at the national level, and was conducted in 2007 by the National Institute of Statistics (NIS).

The sample of ECAM3 comprises about 12000 households. Its sampling basis is the list of counting zones (CZs) defined during the General Census of the Population and the Habitat (GCPH) in 1987.

In the case of ECAM3, 12 survey regions are defined. They comprise the cities of Douala and Yaoundé, in addition to the ten administrative provinces of the country, the Centre province being defined by excluding the city of Yaoundé, and the Littoral province also being defined by excluding the city of Douala. Three strata are defined in each survey region: 
an urban stratum composed of large cities, a semi-urban stratum composed of medium-sized cities, and a rural stratum composed of villages. The regions of Douala and Yaoundé are considered as being wholly urban. The strata involved in the survey therefore add up to 32 strata of which 12 are urban, 10 semi-urban and 10 rural.

Data gathering lasted for 3 months, from September to December 2007. The survey questionnaire was based on 13 modules, namely: 1) Household composition and characteristics; 2) Health; 3) Education; 4) Employment (including the labour of children aged 5 to 17) and the incomes derived from these activities; 5) Anthropometrics and vaccine cover; 6) Housing and equipment; 7) Migration of households; 8) Accessibility to basic infrastructures; 9) Perceptions of poverty; 10) Household capital; 11) Retrospective non-food household expenditures; 12) Daily household expenditures; and 13) The price constituent.

The main welfare measure used in this paper is the household consumption expenditure per adult equivalent. The decision to use a measure based on consumption instead of income as individual welfare indicator in the study, is motivated by several considerations. Firstly, income may be viewed as a welfare measure of opportunity, while consumption may be interpreted as a welfare measure of achievement (28). Since the whole income is not consumed, both income and consumption differ typically (as usual). Consumption is probably the most appropriate indicator if we are concerned about the welfare actually achieved instead of about potential welfare.

Secondly, consumption usually fluctuates less than income. Individuals depend on savings, credit and transfers to smooth out the effects of income fluctuations on their consumption. In particular, it is common practice that temporary income increases are not consumed immediately, but rather spread over long periods of time. We may therefore maintain that consumption provides a more precise and less volatile measure of the permanent income of an individual and of welfare over time.

Thirdly, some researchers and decision makers note that persons surveyed are more willing to reveal their consumption behaviour than their income. Fourthly, a relatively large proportion of the workforce in developing countries is employed in self-employment activities, where it is particularly difficult to measure income accurately. Similarly, many individuals are employed in multiple income-generating activities in a given year, and the income back-pay and aggregation process stemming from different sources may be difficult. Fifthly, the ECAM3 survey used in this study essentially gathered household consumption data, and household income data were underestimated.

In ECAM3, aggregate consumption comprises food expenditures (including meals taken outside the household), non-monetary food consumption resulting from home consumption, and donations; the purchase value of non-durable goods and services; an estimate of the use value of durable goods, and the imputed value of housing for those households who own their accommodations or are housed for free by a third party.

\subsection{Description of the Variables of the Model}

The dependent variable is the logarithm of the « welfare ratio " which is a proxy for the standard of living. The welfare ratio is defined as consumption expenditures per adult equivalent deflated or divided by a national poverty $\operatorname{line}^{2}$. This indicator reflects living standards as a multiple of the poverty line. A unitary value for the welfare ratio means that the household has its level of consumption expenditure per adult equivalent exactly at the level of the poverty line. A higher welfare ratio value means higher living standards.

Independent or explanatory variables are the attributes or characteristics of households. They are the factors likely to exert some influence on household consumption expenditures, and we have retained the following exogenous variables $^{3}$ in specifying regression models: (a) household composition variables (household size), the age group of the household head, his gender and matrimonial status (married); (b) the schooling level of the household head; (c) the area of cultivated land and equity capital; (e) access to infrastructures measured by the time spent to reach those infrastructures (the time spent to reach a food market, the time spent to reach an asphalted road); (f) the region of residence of the household.

The other variables introduced in the model are: «a household member is a member of an association»; " the household head has a spouse»; «the household head obtained a business credit»; the activity sector of the household head; the institutional sector of the household head.

It is generally accepted that consumption expenditures decrease when a person becomes older since his or her productivity decreases, unless that person has a small amount of savings at his disposal to compensate for this loss of productivity and income. This position is maintained by some studies such as those of Gang, Sen and Yun, Datt and Jolliffe, and Rodriguez [31-33]. Three household-head age groups are included among the explanatory variables of the model, namely the $30-39,50-59$, and 60 or more age groups.

Household size is another demographic variable used in this study. It represents the number of individuals living in the same household, and it is a continuous variable. Based on

2 The welfare ratio and its theoretical properties are discussed in a study by Blackorby and Donaldson [28]. More practical applications of the welfare ratio may be found in Ravallion [29]., as well as Deaton and Zaidi[30].

3 There are at least two reasons for not including endogenous variables among the explanatory variables of the model. Firstly, since endogenous variables are likely to be correlated with the error term, the estimation results may be biased. This is not just the case for the variable in question, because the introduction of an endogenous variable in a model can potentially bias all the other parameter estimates. Secondly, even if there are no perceptible biases in the estimation results, the latter will depend on the endogenous variables. Under these conditions, we have not included the household housing characteristics among the explanatory variables, since the latter are likely to be determined by household living standards. Similarly, we have excluded some regressors, that is, variables that include access to basic services such as electricity or potable water, because the endogeneity of these variables of access relative to income may lead to biases in the parameter estimates of the regression. 
studies carried out in many other developing countries, we expect to have a negative relationship between total household size and total consumption per adult equivalent (see for instance, Lanjouw and Ravallion [34]; Deaton and Paxson [35]; Cortes, [36]; Anyanwu [37,38].

Gender is another variable which potentially affects income, and hence household consumption expenditures. It is generally accepted that women are subject to poverty due mainly to the fact that they usually have a low educational level, and lack the opportunity to acquire (or to be an owner of) assets such as land. The feminization of poverty, which has become the subject of many research studies in recent years, is a phenomenon that exists when poverty is more widespread among female household heads than among their male counterparts. The feminization of poverty is explained notably either by the presence of discrimination against women in the labour market, or by the fact that women tend to have a lower level of education and hence receive lower salaries than men (see Anyanwu, [38].). Gender is included among the regressors of the model as a variable called « the household head is a woman».

Moreover, we have also included Education among the exogenous variables of the model of household consumption expenditures. It should be noted that education may affect economic welfare in different ways. For instance, it may influence both the results within economic activities and access to those activities. Education may also limit fertility and hence reduce the number of dependent children in the household. Furthermore, the literature shows that education increases the human capital stock which in turn increases labour productivity and income. Since employment (work) is the most important asset for the poor, increasing their educational level will tend to increase their consumption expenditures.

The variable "Education » is the level of education (or schooling) achieved by the household head. In the ECAM3 surveys, the interviewer asked the persons surveyed about the highest level of education each of them had achieved with success, and codes were used to represent educational levels. The variable "education " is classified into 5 categories: 1. without level, 2. Primary, 3. Secondary first cycle, 4. Secondary second cycle, 5. Higher Education. The variable «Education» is also a dummy variable where each category takes on the value of 1 if the household head has that level of education. The sign of the coefficient of the schooling level may be positive, since on the average higher schooling levels are associated with higher levels of income, and hence with higher expenditures per adult equivalent.

It is assumed that occupation is highly correlated with welfare, since occupations which require low amounts of capital, either human or physical, will be associated with low salaries and consequently with low consumption expenditures. The variables used to capture the occupation of the household head (the institutional sector of activity of the household head) are four in number, namely the household head is an " executive», the household head is a "qualified employee», the household head is an " unskilled worker» and the household head is a "manager». Similarly, the branches in which the household head works are also correlated with welfare. Four large sectors are included among the regressors, namely: the agricultural sector, the industrial sector, the trade sector and the services sector.

We have also included credit among the explanatory variables to test the assumption according to which households that have access to credit are less likely to be poor. In fact, increasing access to the credit market raises household welfare through the availability of investment credit which not only boosts household income (Adugna and Heidhues, [39]), but also smooths out household consumption (Zeller, et al, [40]). This may significantly affect the income of the household by helping its members to take advantage of economic opportunities, thus making it possible for them to escape poverty (Binswinger and Khandker, [41]; Adugna and Heidhues, [39]).

Another explanatory variable is the physical asset « log land», which is defined as the area of land used by households either as property (real estate) mainly in the urban area or as agricultural land in the rural area. Land is considered as the most valuable asset by farmers ${ }^{4}$, and the area of land occupied and/or used by households may serve as an indicator of household income. Richer households generally own large areas of agricultural land, and as a consequence they are able to produce and to consume more than households that are less well-off. Thus, we expect consumption expenditures per adult equivalent to be positively associated with the variable « log land».

The best roads or access to markets are assumed to favour the production of high value products and non-agricultural activities which will contribute to the achievement of higher income levels or to lower poverty levels (see for instance, Canagarajah and Pörtner [42]). The variables of access to the road infrastructures comprise the time span spent to reach a food market and the time span spent to reach an asphalted road. A long time span spent to reach an asphalted road significantly reduces the level of consumption expenditure. The standard explanation here is that the larger the time span spent to reach a good road, the more difficult the access to market is, a situation which limits the options for earning a better livelihood.

In addition to variables of access to infrastructures, we have also created two other variables that are likely to affect consumption household expenditures. There is one variable to measure the matrimonial status of the household head (household head has a spouse) while the other variable captures the participation of the household head in an association (the household head is a member of an association).

4 This has important implications for poverty, since the ownership of land may serve as collateral on credit, in addition to its main function which is to provide shelter. 
The geographic location of household residences according to the ten regions of Cameroon (each household, either urban or rural lives in one of these regions) is also an important determinant of household consumption expenditures (or welfare) ${ }^{5}$. The variable « Region » is a binary variable which represents the region where the household lives. It takes on the value of one if the household resides in the area considered, and the value of zero if not. The regional dummies are the following: region1 (Douala), region2 (Yaoundé), region3 (Adamaoua), region4 (Centre), region5 (East), region6 (Far-North), region7 (Coast T), region8 (North), region9 (North-West), region10 (West), region11 (South), and region12 (South-West). The expected signs of the regional binary variables are ambiguous. However, we expect some of these regional binary variables to have positive signs in case some of the regions retained in the study have more economic activities likely to provide residents with employment.

Several of the variables mentioned above are category-specific (i.e. dummy variables). Consequently, while running our regressions it is necessary to leave one category of variables as a group of reference. Such categories are: region 2 (Yaoundé), male household head, the household head has no spouse, the household head has no education, one household member is not a member of an association, the household head has not obtained a credit, etc.

Table 1 below lists the variables (dependent and exogenous) used to represent these household characteristics in the regression analyses.

Table 1. Descriptive Statistics of the Model's Variables

\begin{tabular}{|c|c|c|c|c|c|c|c|}
\hline & \multirow[t]{2}{*}{ Variables's description } & \multicolumn{3}{|c|}{ Urban } & \multicolumn{3}{|c|}{ Rural } \\
\hline & & Obs & Mean & Std. Dev & Obs & Mean & Std. Dev \\
\hline $\ln y$ & Log of welfare ratio & 6365 & 12.91 & 0.657 & 5026 & 12.346 & 0.599 \\
\hline region1 & Douala & 6365 & 0.164 & 0.37 & 5026 & $\mathbf{0}$ & $\mathbf{0}$ \\
\hline Region3 & Adamaoua & 6365 & 0.048 & 0.215 & 5026 & 0.053 & 0.225 \\
\hline Region4 & centre & 6365 & 0.040 & 0.197 & 5026 & 0.107 & 0.309 \\
\hline Region5 & East & 6365 & 0.042 & 0.201 & 5026 & 0.063 & 0.243 \\
\hline Region6 & Extreme-North & 6365 & 0.096 & 0.295 & 5026 & 0.172 & 0.377 \\
\hline Region7 & littoral & 6365 & 0.056 & 0.230 & 5026 & 0.055 & 0.228 \\
\hline Region8 & North & 6365 & 0.058 & 0.234 & 5026 & 0.079 & 0.271 \\
\hline Region9 & Northwest & 6365 & 0.099 & 0.299 & 5026 & 0.168 & 0.374 \\
\hline Region 10 & West & 6365 & 0.096 & 0.295 & 5026 & 0.135 & 0.342 \\
\hline region 11 & South & 6365 & 0.040 & 0.196 & 5026 & 0.055 & 0.229 \\
\hline region 12 & Southwest & 6365 & 0.095 & 0.293 & 5026 & 0.108 & 0.311 \\
\hline tailm & household size & 6365 & 4.430 & 3.035 & 5026 & 4.574 & 3.108 \\
\hline sexe2 & female & 6365 & 0.258 & 0.438 & 5026 & 0.277 & 0.447 \\
\hline conjoint2 & household head has a spouse & 6365 & 0.493 & 0.499 & 5026 & 0.484 & 0.499 \\
\hline Headaged 2 & Age of head of household: $30-39$ years old & 6365 & 0.292 & 0.454 & 5026 & 0.224 & 0.417 \\
\hline Headaged3 & Age of head of household: $50-59$ years old & 6365 & 0.227 & 0.419 & 5026 & 0.199 & 0.399 \\
\hline Headaged4 & Age of head of household: 60 years or older & 6365 & 0.126 & 0.332 & 5026 & 0.163 & 0.370 \\
\hline education2 & Level of Head's edu: primary & 6365 & 0.294 & 0.455 & 5026 & 0.380 & 0.485 \\
\hline Education3 & Level of Head's edu: secondary 1rst cycle & 6365 & 0.231 & 0.422 & 5026 & 0.154 & 0.361 \\
\hline Education4 & Level of Head's edu: secondary 2nd cycle & 6365 & 0.205 & 0.403 & 5026 & 0.086 & 0.280 \\
\hline Education5 & Level of Head's edu: higher & 6365 & 0.121 & 0.327 & 5026 & 0.026 & 0.159 \\
\hline secteur_ac $\sim 2$ & Industrial sector & 5594 & 0.174 & 0.379 & 4725 & 0.080 & 0.271 \\
\hline secteur ac $\sim 3$ & Trade sector & 5594 & 0.197 & 0.398 & 4725 & 0.060 & 0.238 \\
\hline secteur_ac $\sim 4$ & Services sector & 5594 & 0.479 & 0.499 & 4725 & 0.143 & 0.350 \\
\hline CATEGSIOP1 & Executives & 5596 & 0.104 & 0.306 & 4725 & 0.031 & 0.175 \\
\hline CATEGSIOP2 & skilled employees & 5596 & 0.236 & 0.424 & 4725 & 0.069 & 0.253 \\
\hline CATEGSIOP3 & unskilled workers & 5596 & 0.071 & 0.257 & 4725 & 0.037 & 0.190 \\
\hline CATEGSIOP4 & managers (bosses) & 5596 & 0.043 & 0.205 & 4725 & 0.035 & 0.184 \\
\hline association1 & Is a member of an association & 6364 & 0.509 & 0.499 & 5025 & 0.407 & 0.491 \\
\hline tem8d & Travel time to market place & 6338 & 2.098 & 0.765 & 4936 & 2.877 & 1.098 \\
\hline tem10d & Travel time to reach an asphalted road & 6168 & 1.566 & 1.002 & 4265 & 3.270 & 1.517 \\
\hline logland & Area of land exploited & 1270 & 0.639 & 1.027 & 3645 & 0.633 & 0.750 \\
\hline credit1 & Head obtained a credit & 6365 & 0.047 & 0.212 & 5026 & 0.035 & 0.185 \\
\hline
\end{tabular}

Source: Calculations of the author using the data of the Cameroonian household survey Ecam 3 


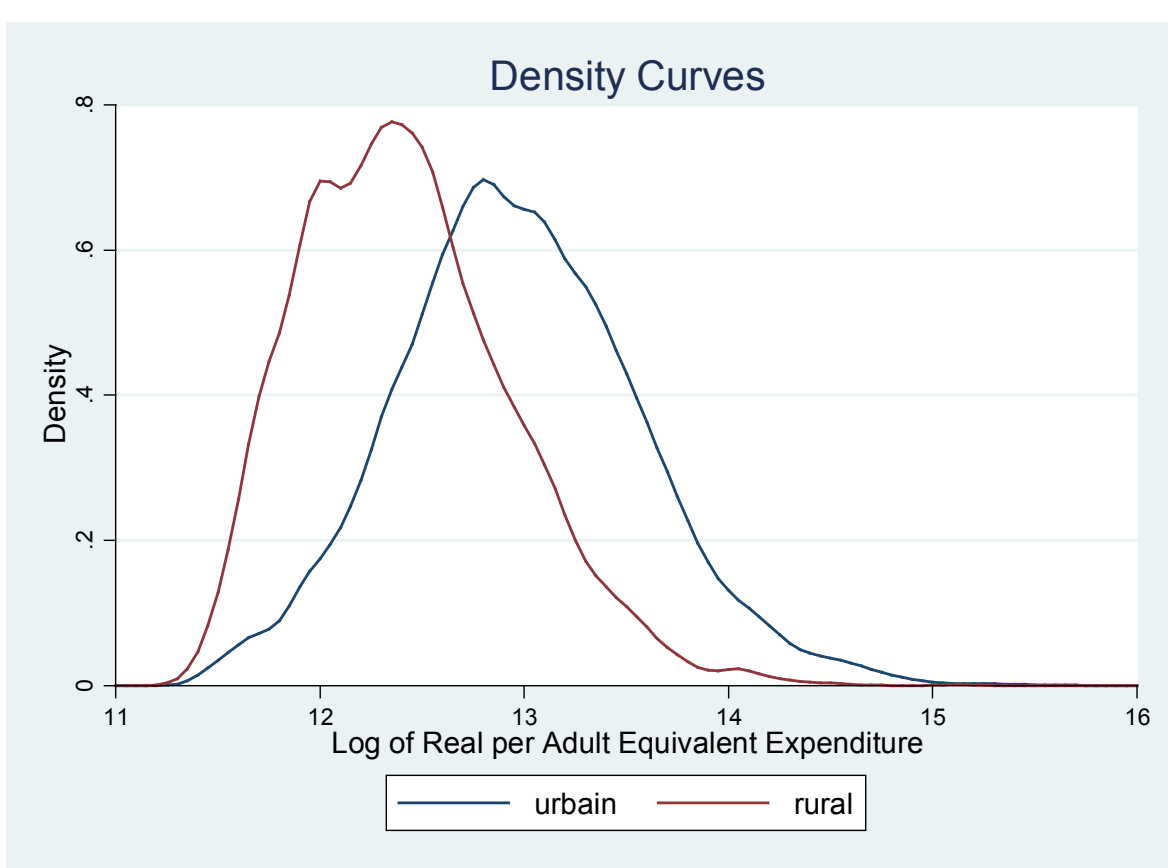

Figure 1. Kernel Densities of Natural Logarithm of Real Consumption Expenditure per Adult Equivalent (lny)

In Cameroon, like any other developing country, there are substantial rural-urban differences in the incidence of poverty. About $39.9 \%$ of the Cameroon population in 2007 was rated to be living below the poverty line (INS, [44] ). The study also finds that $52.1 \%$ and $12.2 \%$ of rural and urban population were in poverty, respectively. In addition, at the national level, the Gini coefficient of total household expenditures per adult equivalent was 0.390 in 2007 . Furthermore in 2007, urban inequality was higher than rural inequality, with Gini coefficients of 0.351 and 0.322 respectively for the urban area and the rural area (INS, [44]).

The rural-urban inequality is further illustrated in Figure 1 of the kernel density estimates of urban and rural household welfare. The urban density is clearly to the right of the rural density, suggesting that for the same level of consumption, there are more people in urban than rural areas. In addition, the difference between rural and urban densities is greater in the right tail of the density, implying that, the urban rich are better off than their rural counterparts to a greater extent than the urban poor are better off than the rural poor.

\section{Results}

\subsection{Regression Results}

Table 2 presents the regression results of the urban and rural welfare models ${ }^{6}$. These results were obtained after testing for the robustness and the reliability of the models. On the one hand, the urban model only explains about $43 \%$ of the variation in welfare, while the rural model only explains $38 \%$ of the variation in welfare among rural households on the other hand. The $\mathrm{R}^{2}$ values in this study should be considered as being reasonable, since they hover approximately around the $\mathrm{R}^{2}$ values of other previous studies in the literature such as, for instance, those of Datt and Jolliffe[32] , Mukherjee and Benson[45] , Datt et al. [46], Datt et al. [47] , as well as Minot and Baulch [48] .

By and large however, both models are statistically significant at the $1 \%$ significance level on the basis of their respective F-statistics, a result which allows us to reject the hypothesis that all the parameters, except for the constant terms of the regressions, are equal to zero.

Since the dependent variable is in the log form, the coefficient estimates of the regression measure the percent changes in expenditures per adult equivalent induced by changes of one unit in the independent variables.

6 Regressions are run with the help of the STATA 10 program. Heteroscedasticity is the econometric problem frequently encountered when cross-section data is being used in regression analysis. To overcome this problem, the ordinary least squares (OLS) is computed with the "robust" option. The "regress " command of the STATA 10 program includes a «robust» option for the estimation of the standard deviation using the Huber-White sandwich estimators. With this "robust" option, the coefficient estimates are exactly the same as those derived from OLS, but the standard deviations take account of the problems of heteroscedasticity and absence of normality. 
Table 2. Determinants of Urban and Rural Consumption Expenditure

\begin{tabular}{|c|c|c|}
\hline Variable & Urban & Rural \\
\hline Douala & $\begin{array}{l}-0.266 \\
(-2.66)^{*}\end{array}$ & dropped) \\
\hline Adamaoua & $\begin{array}{l}-0.090 \\
(-0.82)\end{array}$ & $\begin{array}{l}\mathbf{0 . 0 8 3} \\
(1.37) \\
\end{array}$ \\
\hline Centre & $\begin{array}{l}-0.347 \\
(-4.10) * * *\end{array}$ & $\begin{array}{l}-0.036 \\
(-0.74)\end{array}$ \\
\hline East & $\begin{array}{l}-0.298 \\
(-2.81) * *\end{array}$ & (dropped) \\
\hline Extreme-North & $\begin{array}{l}-\mathbf{- 0 . 1 5 6} \\
(-1.73) \\
\end{array}$ & $\begin{array}{l}-0.192 \\
(-4.14) * * *\end{array}$ \\
\hline Littoral & $\begin{array}{l}-0.590 \\
(-6.90) * * *\end{array}$ & $\begin{array}{l}0.063 \\
(1.06)\end{array}$ \\
\hline North & $\begin{array}{l}-0.14 \\
(-1.62)\end{array}$ & $\begin{array}{l}-0.182 \\
(-3.50) * * *\end{array}$ \\
\hline Northwest & $\begin{array}{l}-0.303 \\
(-3.72)^{* * *}\end{array}$ & $\begin{array}{l}-0.115 \\
(-2.44) \\
\end{array}$ \\
\hline West & $\begin{array}{l}-\mathbf{0 . 3 4 0} \\
(3.70) * * *\end{array}$ & $\begin{array}{l}0.116 \\
(2.39)\end{array}$ \\
\hline South & $\begin{array}{l}-0.346 \\
(-3.72) * * *\end{array}$ & $\begin{array}{l}0.278 \\
(3.95) * * *\end{array}$ \\
\hline Southwest & $\begin{array}{l}-0.088 \\
(-1.05)\end{array}$ & $\begin{array}{l}0.113 \\
(2.19) \\
\end{array}$ \\
\hline household size & $\begin{array}{l}-0.074 \\
(-9.92) * * *\end{array}$ & $\begin{array}{l}-0.081 \\
(-17.76) * * *\end{array}$ \\
\hline Female & $\begin{array}{l}-0.058 \\
(-1.19)\end{array}$ & $\begin{array}{l}-0.070 \\
(-2.53) * *\end{array}$ \\
\hline household head has a spouse & $\begin{array}{l}-0.163 \\
(-3.74) * * *\end{array}$ & $\begin{array}{l}-0.146 \\
(-6.52) * * *\end{array}$ \\
\hline Age of head of household: $30-39$ years old & $\begin{array}{l}-0.066 \\
(-1.55)\end{array}$ & $\begin{array}{l}-0.065 \\
(-2.96) * *\end{array}$ \\
\hline Age of head of household: $50-59$ years old & $\begin{array}{c}-0.108 \\
(-2.57)\end{array}$ & $\begin{array}{l}-0.128 \\
(-5.48) *\end{array}$ \\
\hline Age of head of household: 60 years or older & $\begin{array}{l}0.070 \\
(1.49) \\
\end{array}$ & $\begin{array}{c}-0.048 \\
(-1.96) \\
\end{array}$ \\
\hline Level of Head's edu: primary & $\begin{array}{l}0.063 \\
(1.36) * * *\end{array}$ & $\begin{array}{l}0.068 \\
(3.18)^{* *}\end{array}$ \\
\hline Level of Head's edu: secondary 1 rst cycle & $\begin{array}{l}0.207 \\
(4.04) * * *\end{array}$ & $\begin{array}{l}0.154 \\
(5.25) * * *\end{array}$ \\
\hline Level of Head's edu: secondary 2 nd cycle & $\begin{array}{l}0.278 \\
(4.76) * * *\end{array}$ & $\begin{array}{l}0.188 \\
(4.37) * * *\end{array}$ \\
\hline Level of Head's edu: higher & $\begin{array}{l}0.629 \\
(8.01)^{* * *}\end{array}$ & $\begin{array}{l}0.348 \\
(3.69) * * *\end{array}$ \\
\hline Industrial sector & $\begin{array}{l}0.019 \\
(0.42)\end{array}$ & $\begin{array}{l}0.074 \\
(2.01)\end{array}$ \\
\hline Trade sector & $\begin{array}{l}0.261 \\
(4.97) * * *\end{array}$ & $\begin{array}{l}0.223 \\
(4.41) * * *\end{array}$ \\
\hline Services sector & $\begin{array}{l}0.218 \\
(4.72)^{* * * *}\end{array}$ & $\begin{array}{l}0.068 \\
(1.60) \\
\end{array}$ \\
\hline Executives & $\begin{array}{l}0.33 \\
(4.78) * * *\end{array}$ & $\begin{array}{l}0.344 \\
(4.47)^{* * *}\end{array}$ \\
\hline skilled employees & $\begin{array}{l}0.077 \\
(1.49)\end{array}$ & \begin{tabular}{|l|}
0.118 \\
$(2.43)$ \\
\end{tabular} \\
\hline unskilled workers & $\begin{array}{l}-\mathbf{- 0 . 0 8 9} \\
(-1.49) \\
\end{array}$ & $\begin{array}{l}-\mathbf{- 0 . 0 2 9} \\
(-0.56) \\
\end{array}$ \\
\hline managers (bosses) & $\begin{array}{l}0.244 \\
(2.64) *\end{array}$ & $\begin{array}{l}0.182 \\
(3.84) * * *\end{array}$ \\
\hline Head is a member of an association & $\begin{array}{l}\mathbf{0 . 0 7 5} \\
(2.34) \\
\end{array}$ & $\begin{array}{l}\text { 3.04 } \\
(3.04) * *\end{array}$ \\
\hline Travel time to market place & $\begin{array}{l}-0.057 \\
(-2.05)^{* *}\end{array}$ & $\begin{array}{l}-0.024 \\
(-2.74) *\end{array}$ \\
\hline Travel time to reach an asphalted road & $\begin{array}{l}-0.027 \\
(-1.90)\end{array}$ & $\begin{array}{l}-0.019 \\
(-2.89) * *\end{array}$ \\
\hline Area of land exploited & $\begin{array}{l}\text { 0.048 } \\
(3.18) * *\end{array}$ & $\begin{array}{l}0.065 \\
(4.59) * * *\end{array}$ \\
\hline Head obtained a credit & $\begin{array}{l}0.201 \\
(3.09) * *\end{array}$ & $\begin{array}{l}0.173 \\
(3.56)^{* * *}\end{array}$ \\
\hline \multirow[t]{5}{*}{ intercept } & $\begin{array}{l}13.287 \\
(123.30) * * *\end{array}$ & $\begin{array}{l}12.827 \\
(212.46)^{* * * *}\end{array}$ \\
\hline & $\mathrm{R2}=\mathbf{0 . 4 3}$ & $\mathrm{R} 2=\mathbf{0 . 3 8}$ \\
\hline & F-statistic $(33,1147)=21.77$ & F-statistic $(31,3004)=47.91$ \\
\hline & Prob. $>$ F $=0.000$ & Prob. $>$ F $=0.000$ \\
\hline & 1181 & 3036 \\
\hline
\end{tabular}

Notes: $R$ Robust t- statistics are between parentheses.

*** Significant at the 1\% level; ** significant at the 5\% level; * significant at the $10 \%$ level.

Source: Calculations of the author using the data of the Cameroonian household survey Ecam 3 
We find welfare effects statistically significant at the 5\% and $1 \%$ significance levels, respectively for the household heads age groups of 30-39 and 50-59 in the rural area. Households whose heads are older in the rural area ceteris paribus, tend to enjoy a lower welfare level than those whose heads are younger. By contrast, the household welfare level in the urban area does not seem to be determined by the age of the household head. Similar results were found by Mukherjee and Benson[45] in their study on the determinants of poverty in Malawi.

The regression results show that there also exists a welfare gender dimension. In effect, the gender of the household head is statistically significant at the $5 \%$ level in the rural welfare model and insignificant at the same level in the urban welfare model. In the same vein, the negative sign of the household head's gender reflects the fact that when a woman is a female household head, her welfare level is lower than that of a male household head. This result could be due to the multiple responsibilities and to the many constraints that women in Sub-Saharan Africa face in trying to have access to the same resources and services that men enjoy in this region (Cleaver, [49] ). Similar results are found in a study by Datt et al. [47] (2000) in which they analyze the determinants of poverty in Mozambique.

The estimation results also show that married household heads have lower welfare levels than their unmarried counterparts.

As regards household size (i.e. the number of persons living in the household), we find coefficients that are negative and statistically significant at the $1 \%$ significance level both in the urban and rural areas. This result is frequent (common) in studies dealing with welfare (see for instance, Lipton and Ravallion [50]; Lanjouw and Ravallion [34];,), and it implies that the welfare enjoyed by household members is reduced by the fact of having larger-sized households. Following a one unit change in household size, the welfare level of the household declines by about $7.4 \%$ and $8.1 \%$ in urban and rural areas respectively. This reflects high dependence levels for households with relatively more members who are children or when household members are unemployed or have been badly paid, a situation which altogether lead to a reduction in the consumption expenditure per adult equivalent of the household.

The results stemming from the rural and urban regression equations indicate that education is an important determinant of expenditures per adult equivalent. The maximum level of education achieved by the household head contributes significantly to welfare both in the urban and rural areas. The coefficient estimates of educational levels that are significant either at the $1 \%$ or at the $5 \%$ significance levels are systematically positive, thus confirming the assumption that the educational level achieved improves or reinforces welfare. The increase in urban welfare (except for the primary level of education) is higher than that of the rural area, thus probably corroborating the fact that there would be very few lucrative economic opportunities from education in the rural area of Cameroon.

The institutional sector where the individual exerts his activity and the branch in which he works are also correlated with welfare. The estimation results of the regression model show that there is a premium for a household whose head is a manager, a qualified employee or a director. In the urban area, and respectively in the rural area a household whose head is a manager has a level of consumption per adult equivalent which is $33 \%$ (respectively $34.4 \%$ in the rural area) higher than that of a household whose head is self-employed, a mother's help or an apprentice. For a household whose head is a director, this gain amounts to $24 \%$ in the city and $18 \%$ in the countryside.

In addition, regarding the activity branch of the household head, the estimation results of the regression model also show that there is a premium (gain) for households whose heads work in industry, trade, and services as compared with households whose heads work in agriculture.

Actually, the fact of working in the trade sector in the urban area induces an increase in consumption per adult equivalent of $26 \%$ relative to a household whose head works in agriculture; in the rural area this percentage amounts to $22.3 \%$. Similarly, the fact of working in the services sector in the urban area leads to an increase in consumption per adult equivalent of $22 \%$ relative to a household whose head works in agriculture; this percentage is equal to $7 \%$ in the rural area. The estimation results of the model confirm the fact that there is a fall in consumption if the household head works in agriculture, thus testifying to the vulnerability of the household concerned.

Access to credit by a household head who plans to engage in agriculture or business also plays an important role in the determination of household living standards. In effect, we note that access to credit by the household head positively and significantly affects living standards both in the urban and rural areas. In the rural area, the coefficient associated with the variable « access to credit » is significant at the $1 \%$ significance level ${ }^{7}$. In addition, the average welfare level of households which have obtained a credit in the rural area is $17.4 \%$ higher than that of households that did not have access to credit. This result is similar to that of the study by Geda et al. [51] on Ethiopia according to which credit is an important component in smoothing out household consumption and, as a consequence, it is pro poor because it increases household welfare.

Production assets and issued capital are positively associated with household consumption and welfare. In effect, the ownership of land increases the level of household consumption per adult equivalent; the impact of this variable is however weak, and this tends to suggest that other elements such as the means of production should be associated to land.

7 It is opportune to note that access to credit in the urban area is significant at the $5 \%$ level of significance. 
In addition, membership in any association improves the level of consumption per adult equivalent by $6 \%$ and $7.5 \%$ respectively in the rural and urban areas. Associations in effect play an important role in improving access to credit when it comes to financing income-generating activities, among others. Moreover, associations more often play the role of insurance (companies) for their members in case of illness, death, etc. However, it should be noted that there exist a double causality, since the level of consumption can incite a household to belong to an association.

The regressions also highlight the impact of access to infrastructures on the welfare ratio. The results derived from regression analysis suggest that the absence of infrastructures contribute to the exclusion of some households from the market and from income-generating opportunities. The coefficient estimates of the average time span spent to reach an asphalted road or a food market are significant in the rural area. The negative signs of the coefficients show the absence of infrastructures and the enclosure of rural areas; a situation which may induce high transaction costs that are likely to reduce the welfare of populations.

Finally, regression results also show differences between the regions of the country. In the urban area and compared with Yaoundé which is the region of reference for our model, all the other regions, are disadvantaged relative to Yaoundé. Concerning the rural area, all the regions (save for the Extreme-North, the North, and the Northwest) have an advantage relative to Yaoundé.

\subsection{The Results of the Quantile Regressions}

On the whole, the results of quantile regressions actually confirm the fact that the levels of expenditure per adult equivalent of the different quantile expenditure groups are affected by different factors. These different expenditure groups not only face different challenges, but the challenges of each group also depend on the particular type of households concerned, i.e. whether these households belong to urban or rural areas.

Table 3 below shows that the pseudo- $\mathrm{R}_{\mathrm{s}}{ }^{2}$ of quantile regressions lie between 0.24 and 0.36 , thus indicating that the coefficient estimates derived from our model perform reasonably well.

In terms of geographic sites and by comparison with households residing in Yaoundé, the study results show that regional variables have negative effects on household consumption in urban areas, except for the consumption of households belonging to the 90th percentile of the Extreme-North region. On the other hand, in rural areas and compared with households residing in Yaoundé, the results show that regional variables (South-West, South, West, and Littoral) have insignificant positive effects on consumption whatever quantile is considered, whereas the regional variables of the North-West, North, and Extreme-North rather have negative effects on household consumption.

As for the OLS regressions results, household size is significant and negatively associated with consumption expenditures per adult equivalent across all the quantiles of the distribution of expenditures in the urban and rural areas. This result not only indicates that large-sized families usually have lower expenditures per adult equivalent, but it is also similar to the results of other studies such as that of Lanjouw and Ravallion[34]; which finds that large-sized households are more likely to fall into poverty than small-sized ones.

As regards the gender of the household head, quantile regressions results show that households whose heads are females have a negative relationship with welfare (except for the households of the 10th quantile of the urban area), and these results are very significant for the 50th and 90th percentiles in the rural area. A large number of studies have shown that households headed by men tend to fare better than those headed by women (Barros et al. [52]), because households headed by women not only have more limited access to resources than men, but they also tend to experience more discriminations (World Bank, [53];). This situation underlines the constant need to include gender-specific policies in the formulation of policies aimed at alleviating poverty.

Age has an insignificantly positive association with household living standards, except for the household head's age group of 60 and more, and for the 50th and 90th quantiles of the consumption distribution in the rural area. In effect, the study results suggest that the variable «household heads belonging to the 50 to 59 age group» is significant for the 50th and 90th quantiles in the rural area. On the other hand, the variable « the household head belong to the 60 -and-more age group» is positively related to welfare for the $50^{\text {th }}$ and $90^{\text {th }}$ quantiles of the distribution of consumption both in the rural and urban areas. This result suggests that households headed by the oldest household heads enjoy a higher level of welfare in the upper quantiles of the distribution of consumption expenditures. This result is different from the one derived from OLS regressions according to which the older members of the household are negatively associated with consumption expenditures per adult equivalent.

The educational level of the household head is positively linked to household consumption expenditures at all the quantiles of the distribution of expenditures both in the urban and rural areas. The first-cycle and second-cycle levels of secondary education significantly increase household consumption expenditures at the $10^{\text {th }}$ quantile of the distribution of consumption expenditures both in the urban and rural areas. When higher education is considered, and when one moves from the 10th quantile to the 90th quantile of the consumption expenditures distribution, one notes that in the urban and rural areas, the coefficients increase and reach their highest levels at the 90th quantile, which means that education has a stronger effect on the welfare of rich households. For rich households in the urban area, each additional year of education increases welfare by 83 percent, whereas for poor households each additional year of 
education only increases welfare by 65 percent. For rich households in the rural area, each additional year of education increases welfare by 16 percent, while for poor households, each additional year of education increases welfare by only 13.5 percent.

An examination of the sector in which the household head is employed reveals that household heads employed in trade have a positive relationship with welfare for all the three quantiles of the welfare distribution in both the urban and rural areas. As for the results of the OLS regressions, they are significant for the 50th and 90th percentiles of the distribution of household expenditures in the urban area.

The household heads employed in the industrial sector have a positive relationship with welfare for the 50th and 90th percentiles of the distribution of household expenditures in the urban area, and for all the three quantiles of the distribution of household expenditures in the rural area. Contrary to the OLS regression results, household heads who work in industry have a negative relationship with consumption for the 10th quantile of the distribution of household expenditures in the urban area.

Household heads working in the services sector have a positive relationship with consumption for the three quantiles of the expenditure distribution in the urban area, and this result is similar to the result obtained from OLS regressions. On the other hand, in the rural area, household heads working in the services sector have a positive relationship with consumption only for the $50^{\text {th }}$ and $90^{\text {th }}$ percentiles of the distribution of expenditures, whereas those belonging to the 10th quantile have a negative relationship with consumption, thus indicating the disadvantage associated with working in this sector.

Households whose heads are executives, skilled employees, and managers (bosses) tend to be more well-off for the three quantiles of the distribution of expenditures both in the urban and rural areas. This result is similar to that obtained with OLS regressions. By contrast, households whose heads are unskilled workers tend to be poor for the three quantiles of the distribution of expenditures in the urban area, and for the $10^{\text {th }}$ quantile in the rural area. Contrary to the results derived from OLS regressions, households whose heads are unskilled workers tend to be rich for the 50th and 90th percentiles of the distribution of expenditures in the rural area.

Quantile regressions provide the evidence of a higher positive impact in terms of access to land in the three quantiles of the distribution of consumption expenditures in the rural area, thus indicating the higher significance of the role played by agriculture for the households of this area.

In the rural area, the average time span spent to reach a market place or the time span spent to reach an asphalted road are positively correlated with the welfare of a household belonging to the $90^{\text {th }}$ percentile of the distribution of household consumption expenditures. In particular, the average time period spent to reach an asphalted road has a stronger positive impact on the consumption of the rural households belonging to the $90^{\text {th }}$ percentile of the distribution of expenditures. These results are contrary to those derived from the OLS regressions which rather show the existence of a negative relationship between the variables "time span" and the household consumption.

The fact of being a member of an association has a positive but insignificant effect on the consumption of households belonging to the 10th, 50th and 90th quantiles of the distribution of consumption expenditures in the urban area. This result is similar to that obtained with the help of OLS regressions. In the rural area on the contrary, to be a member of an association has a significant positive effect only on the consumption of the households belonging to the $10^{\text {th }}$ quantile of the expenditures distribution.

As for the results derived with OLS regressions, the fact that a credit is obtained by a household head has a positive effect on the consumption of a household in the three quantiles of the distribution of consumption expenditures in both the urban and rural areas. This result is significant for the three quantiles of the distribution of consumption expenditures in the rural area.

Table 3. Quantile Regression Results

\begin{tabular}{|c|c|c|c|c|c|c|c|c|}
\hline \multirow[b]{2}{*}{ Variables } & \multicolumn{4}{|c|}{ Urban } & \multicolumn{4}{|c|}{ Rural } \\
\hline & OLS & 10th & 50th & 90th & OLS & 10th & 50th & 90th \\
\hline Douala & $\begin{array}{c}-0.266 \\
(-2.66) * * *\end{array}$ & $-0.286(-2.17)$ & $-0.241(-1.38)$ & $\begin{array}{c}-0.421 \\
(-1.89)\end{array}$ & dropped) & & & \\
\hline Adamaoua & $\begin{array}{l}-0.090 \\
(-0.82)\end{array}$ & $-0.188(-1.35)$ & $-0.030(-0.16)$ & $-0.048(-0.37)$ & $\begin{array}{l}\mathbf{0 . 0 8 3} \\
(1.37)\end{array}$ & $\begin{array}{c}-0.033 \\
(-0.42)\end{array}$ & $\begin{array}{c}0.160 \\
(2.27)\end{array}$ & $\begin{array}{r}0.186 \\
(1.50)\end{array}$ \\
\hline Centre & $\begin{array}{c}-0.347 \\
(-4.10) *\end{array}$ & $-0.333(-3.00)^{* * *}$ & $-0.304(-2.11)$ & $\begin{array}{c}-0.544 \\
(1.54)^{* *}\end{array}$ & $\begin{array}{l}-0.036 \\
(-0.74)\end{array}$ & $\begin{array}{c}0.033 \\
(\mathbf{0 . 5 0})\end{array}$ & $\begin{array}{l}-0.100 \\
(-1.59)\end{array}$ & $\begin{array}{l}-0.163 \\
(-1.51)\end{array}$ \\
\hline East & $\begin{array}{c}-0.298 \\
(-2.81)^{* *}\end{array}$ & $-0.350(-2.55)$ & $-0.164(-0.93)$ & $\begin{array}{l}-0.376 \\
(-1.73)\end{array}$ & (dropped) & & & \\
\hline Extreme-North & $\begin{array}{l}-0.156 \\
(-1.73)\end{array}$ & $-0.413(-3.75) *$ & $-0.091(-0.66)$ & $0.010(0.06)$ & $\begin{array}{c}-0.192 \\
(-4.14)^{*}\end{array}$ & $\begin{array}{c}-\mathbf{- 0 . 2 6 0} \\
(-4.07) \\
*\end{array}$ & $\begin{array}{c}-0.176 \\
(-3.03)^{* *}\end{array}$ & $\begin{array}{l}-0.159 \\
(-1.62)\end{array}$ \\
\hline Littoral & $\begin{array}{l}-0.590 \\
(-6.90) *\end{array}$ & $-0.792(-3.78)^{*}$ & $-0.518(-2.99)$ & $\begin{array}{c}-0.659 \\
(-3.79)^{*}\end{array}$ & $\begin{array}{l}0.063 \\
(1.06)\end{array}$ & $\begin{array}{c}0.043 \\
(0.56)\end{array}$ & $\begin{array}{c}0.138 \\
(1.81)\end{array}$ & $\begin{array}{r}0.183 \\
(1.38)\end{array}$ \\
\hline North & $\begin{array}{c}-0.14 \\
(-1.62)\end{array}$ & $-0.162(-1.45)$ & $-0.176(-1.23)$ & $\begin{array}{c}-0.127 \\
(-0.71)\end{array}$ & $\begin{array}{c}-0.182 \\
(-3.50)^{*}\end{array}$ & $\begin{array}{c}-0.245 \\
(-3.53) \\
*\end{array}$ & $\begin{array}{l}-0.135 \\
(-2.16)\end{array}$ & $\begin{array}{l}-0.217 \\
(-2.06)\end{array}$ \\
\hline Northwest & $\begin{array}{c}-0.303 \\
(-3.72)^{*}\end{array}$ & $-0.390(-3.87)^{*}$ & $-0.284(-2.22)$ & $\begin{array}{c}-0.260 \\
(-1.50)\end{array}$ & $\begin{array}{l}-0.115 \\
(-2.44)\end{array}$ & $\begin{array}{c}-\mathbf{- 0 . 1 2 3} \\
(-3.53) \\
*\end{array}$ & $\begin{array}{l}-0.127 \\
(-2.14)\end{array}$ & $\begin{array}{l}-0.116 \\
(-1.14)\end{array}$ \\
\hline
\end{tabular}




\begin{tabular}{|c|c|c|c|c|c|c|c|c|}
\hline West & $\begin{array}{l}-0.340 \\
(3.70)^{*}\end{array}$ & $-0.403(-3.84)^{*}$ & $-0.460(-1.85)$ & $\begin{array}{c}-0.460 \\
(-2.68)^{* * * *}\end{array}$ & $\begin{array}{l}0.116 \\
(2.39)\end{array}$ & $\begin{array}{r}0.088 \\
(1.35)\end{array}$ & $\begin{array}{r}0.105 \\
(1.70)\end{array}$ & $\begin{array}{l}0.045 \\
(0.43)\end{array}$ \\
\hline South & $\begin{array}{c}-0.346 \\
(-3.72)^{*}\end{array}$ & $-0.314(-2.46)$ & $-0.289(-1.76)$ & $\begin{array}{c}-0.594 \\
(-2.90)^{* *}\end{array}$ & $\begin{array}{c}0.278 \\
(3.95)^{*}\end{array}$ & $\begin{array}{r}0.214 \\
(2.58)\end{array}$ & $\begin{array}{r}0.111 \\
(1.71)\end{array}$ & $\begin{array}{l}0.182 \\
(1.10)\end{array}$ \\
\hline Southwest & $\begin{array}{l}-0.088 \\
(-1.05) \\
\end{array}$ & $\mathbf{- 0 . 0 3 9}(-\mathbf{- 0 . 3 8})$ & $-0.047(-0.35)$ & $\begin{array}{c}-0.217 \\
(-1.21)\end{array}$ & $\begin{array}{l}0.113 \\
(2.19)\end{array}$ & $\begin{array}{r}0.058 \\
(0.84) \\
\end{array}$ & $\begin{array}{l}0.138 \\
(2.08)\end{array}$ & $\begin{array}{r}0.139 \\
(1.22) \\
\end{array}$ \\
\hline household size & $\begin{array}{c}-0.074 \\
(-9.92)^{*}\end{array}$ & $-0.087(3.84)$ & $\begin{array}{c}-0.081 \\
(-11.26)^{*}\end{array}$ & $\begin{array}{c}-0.083 \\
(-6.04)^{*}\end{array}$ & $\begin{array}{c}-0.081 \\
(-17.76)^{*}\end{array}$ & $\begin{array}{c}-0.071 \\
(-24.04) \\
*\end{array}$ & $\begin{array}{l}-0.048 \\
(-1.32)\end{array}$ & $\begin{array}{l}0.006 \\
(0.10)\end{array}$ \\
\hline Female & $\begin{array}{l}-0.058 \\
(-1.19)\end{array}$ & $0.014(0.23)$ & $-0.016(-0.21)$ & $\begin{array}{l}-\mathbf{- 0 . 0 3 9} \\
(-0.39)\end{array}$ & $\begin{array}{l}-0.070 \\
(-2.53)\end{array}$ & $\begin{array}{c}-0.080 \\
(-2.35)\end{array}$ & $\begin{array}{c}-0.090 \\
(-25.87)^{*}\end{array}$ & $\begin{array}{l}-0.002 \\
(-9.20)^{*}\end{array}$ \\
\hline $\begin{array}{l}\text { household head } \\
\text { has a spouse }\end{array}$ & $\begin{array}{c}-0.163 \\
(-3.74)^{*}\end{array}$ & $-0.032(-0.61)$ & $-0.164(-2.50)$ & $-0.221(-2.52)$ & $\begin{array}{l}-0.146 \\
(-6.52)^{*}\end{array}$ & $\begin{array}{c}-0.075 \\
(-2.82) \\
* *\end{array}$ & $\begin{array}{r}-0.001 \\
(-0.80)\end{array}$ & $\begin{array}{r}0.001 \\
(0.32)\end{array}$ \\
\hline $\begin{array}{l}\text { Age of head of } \\
\text { household: } \\
30-39 \text { years old }\end{array}$ & $\begin{array}{l}-0.066 \\
(-1.55)\end{array}$ & $-0.065(-1.13)$ & $-0.069(-0.97)$ & $-0.123(1.37)$ & $\begin{array}{l}-0.021 \\
(-2.96)\end{array}$ & $\begin{array}{r}-0.021 \\
(-0.73)\end{array}$ & $\begin{array}{l}-0.082 \\
(-2.26)\end{array}$ & $\begin{array}{l}-0.036 \\
(-0.56)\end{array}$ \\
\hline $\begin{array}{l}\text { Age of head of } \\
\text { household: } \\
50-59 \text { years old }\end{array}$ & $\begin{array}{l}-0.108 \\
(-2.57)\end{array}$ & $-0.105(-1.87)$ & $-0.111(-1.63)$ & $\begin{array}{c}-0.082 \\
(-0.95)\end{array}$ & $\begin{array}{c}-0.128 \\
(-5.48) * *\end{array}$ & $\begin{array}{r}-0.088 \\
(-2.99)\end{array}$ & $\begin{array}{r}0.029 \\
(1.12)\end{array}$ & $\begin{array}{l}0.021 \\
(0.45)\end{array}$ \\
\hline $\begin{array}{l}\text { Age of head of } \\
\text { household: } 60 \\
\text { years or older }\end{array}$ & $\begin{array}{l}0.070 \\
(1.49)\end{array}$ & $-0.003(-0.06)$ & $0.057(0.78)$ & $0.120(1.36)$ & $\begin{array}{l}-0.048 \\
(-1.96)\end{array}$ & $\begin{array}{r}-0.075 \\
(-2.54)\end{array}$ & $\begin{array}{c}0.119 \\
(3.14)^{* *}\end{array}$ & $\begin{array}{l}0.069 \\
(1.05)\end{array}$ \\
\hline $\begin{array}{l}\text { Level of Head's } \\
\text { edu: primary }\end{array}$ & $\begin{array}{c}0.063 \\
(1.36)^{*}\end{array}$ & 0.095 (1.68) & $\begin{array}{c}0.147 \\
(2.54)\end{array}$ & $0.015(0.17)$ & $\begin{array}{c}0.068 \\
(3.18)^{* *}\end{array}$ & $\begin{array}{r}\mathbf{0 . 0 3 9} \\
(1.47) \\
\end{array}$ & $\begin{array}{r}0.153 \\
(2.80)^{*}\end{array}$ & $\begin{array}{r}0.179 \\
(1.85) \\
\end{array}$ \\
\hline $\begin{array}{l}\text { Level of Head's } \\
\text { edu: secondary } \\
\text { 1rst cycle }\end{array}$ & $\begin{array}{c}4.04 \\
(4.04)^{*}\end{array}$ & $0.304(4.52)^{*}$ & $0.216(2.54)$ & 0.148 (1.32 ) & $\begin{array}{c}0.154 \\
(5.25)^{*}\end{array}$ & $\begin{array}{c}0.144 \\
(3.77)^{*}\end{array}$ & $\begin{array}{c}0.210 \\
(2.12)^{* * *}\end{array}$ & $\begin{array}{l}0.032 \\
(0.20)\end{array}$ \\
\hline $\begin{array}{l}\text { Level of Head's } \\
\text { edu: secondary } \\
\text { 2nd cycle }\end{array}$ & $\begin{array}{l}0.278 \\
(4.76)^{*}\end{array}$ & $0.318(4.14)^{*}$ & $3.55(3.55)^{*}$ & $0.138(1.13)$ & $\begin{array}{c}0.188 \\
(4.37)^{*}\end{array}$ & $\begin{array}{c}0.141 \\
(2.79)^{*} \\
*\end{array}$ & $\begin{array}{r}0.130 \\
(1.92) \\
\end{array}$ & $\begin{array}{l}0.195 \\
(1.71)\end{array}$ \\
\hline $\begin{array}{l}\text { Level of Head's } \\
\text { edu: higher }\end{array}$ & $\begin{array}{l}0.629 \\
(8.01)^{*}\end{array}$ & $\begin{array}{c}0.647 \\
(6.80) *\end{array}$ & $0.580(4.55)^{*}$ & $0.830(6.15)^{*}$ & $\begin{array}{c}0.348 \\
(3.69)^{*}\end{array}$ & $\begin{array}{c}0.135 \\
(0.141) \\
\end{array}$ & $\begin{array}{c}0.179 \\
(2.40)^{* *}\end{array}$ & $\begin{array}{l}0.157 \\
(1.29)\end{array}$ \\
\hline Industrial sector & $\begin{array}{l}0.019 \\
(0.42)\end{array}$ & $-0.016(-0.28)$ & $0.051(0.63)$ & $0.078(0.87)$ & $\begin{array}{l}0.074 \\
(2.01)\end{array}$ & $\begin{array}{r}0.050 \\
(1.13) \\
\end{array}$ & $\begin{array}{c}0.104 \\
(3.31)^{* *}\end{array}$ & $\begin{array}{c}0.168 \\
(3.16)^{* *}\end{array}$ \\
\hline Trade sector & $\begin{array}{c}0.261 \\
(4.97)^{*}\end{array}$ & $0.203(3.27) * *$ & $0.276(3.36) * *$ & $\begin{array}{c}0.282(2.73) \\
* * * \\
\end{array}$ & $\begin{array}{c}0.223 \\
(4.41)^{*}\end{array}$ & $\begin{array}{r}0.082 \\
(0.76) \\
\end{array}$ & $\begin{array}{r}0.111 \\
(1.21)\end{array}$ & $\begin{array}{l}0.028 \\
(0.16)\end{array}$ \\
\hline Services sector & $\begin{array}{l}0.218 \\
(4.72)^{*}\end{array}$ & $0.105(1.93)$ & $0.176(2.51)$ & $\begin{array}{c}0.251(2.69) \\
* * * \\
\end{array}$ & $\begin{array}{l}\mathbf{0 . 0 6 8} \\
(1.60) \\
\end{array}$ & $\begin{array}{r}-0.022 \\
(-0.42) \\
\end{array}$ & $\begin{array}{r}0.105 \\
(2.14) \\
\end{array}$ & $\begin{array}{c}0.241 \\
(2.88)^{* *}\end{array}$ \\
\hline Executives & $\begin{array}{c}0.33 \\
(4.78)^{*}\end{array}$ & $0.363(3.98) *$ & $0.391(3.34) * *$ & $0.340(2.60)$ & $\begin{array}{c}0.344 \\
(4.47)^{*}\end{array}$ & $\begin{array}{c}0.454 \\
(4.75)^{*}\end{array}$ & $\begin{array}{r}0.127 \\
(3.86)^{*}\end{array}$ & $\begin{array}{l}0.231 \\
(3.93)\end{array}$ \\
\hline $\begin{array}{c}\text { skilled } \\
\text { employees }\end{array}$ & $\begin{array}{l}0.077 \\
(1.49)\end{array}$ & $0.147(2.28)$ & $0.154(1.74)$ & $0.039(0.37)$ & $\begin{array}{l}0.118 \\
(2.43) \\
\end{array}$ & $\begin{array}{r}0.095 \\
(1.55) \\
\end{array}$ & $\begin{array}{c}0.096 \\
(2.35)^{* *}\end{array}$ & $\begin{array}{c}0.002 \\
(0.04)^{*}\end{array}$ \\
\hline $\begin{array}{l}\text { unskilled } \\
\text { workers }\end{array}$ & $\begin{array}{l}-0.089 \\
(-1.49) \\
\end{array}$ & $-0.088(-1.08)$ & $-0.013(-0.13)$ & $\begin{array}{c}-0.202 \\
(-1.49) \\
\end{array}$ & $\begin{array}{l}-0.029 \\
(-0.56) \\
\end{array}$ & $\begin{array}{c}-0.000 \\
-0.00) \\
\end{array}$ & $\begin{array}{r}0.051 \\
(2.27) \\
\end{array}$ & $\begin{array}{l}0.033 \\
(0.82)\end{array}$ \\
\hline $\begin{array}{l}\text { managers } \\
\text { (bosses) }\end{array}$ & $\begin{array}{c}0.244 \\
(2.64)^{* * * *}\end{array}$ & $0.067(0.72)^{*}$ & $0.249(2.03)$ & $0.331(2.25)$ & $\begin{array}{c}0.182 \\
(3.84)^{*}\end{array}$ & $\begin{array}{c}0.150 \\
(2.67)^{*} \\
* *\end{array}$ & $\begin{array}{r}0.058 \\
(3.90)^{*}\end{array}$ & $\begin{array}{c}0.136 \\
(5.36)^{*}\end{array}$ \\
\hline $\begin{array}{c}\text { Head is a } \\
\text { member of an } \\
\text { association }\end{array}$ & $\begin{array}{l}0.075 \\
(2.34)\end{array}$ & $0.058(1.42)$ & $0.079(1.48)$ & $0.091(0.90)$ & $\begin{array}{c}3.04 \\
(1.40)\end{array}$ & $\begin{array}{c}\mathbf{0 . 0 7 8} \\
(3.19) \\
* *\end{array}$ & $\begin{array}{c}-0.236 \\
(-2.56)^{* *}\end{array}$ & $\begin{array}{l}-0.016 \\
(-0.14)\end{array}$ \\
\hline $\begin{array}{l}\text { Travel time to } \\
\text { market place }\end{array}$ & $\begin{array}{c}-0.057 \\
(-2.05)^{* *}\end{array}$ & $-0.035(-1.63)$ & $-0.068(2.13)$ & $\begin{array}{l}-0.065 \\
(-1.63) \\
\end{array}$ & $\begin{array}{c}-0.024 \\
(-2.74) * * *\end{array}$ & $\begin{array}{c}-2.49 \\
(-2.49) \\
\end{array}$ & $\begin{array}{r}0.130 \\
(0.94) \\
\end{array}$ & $\begin{array}{l}0.052 \\
(0.27)\end{array}$ \\
\hline $\begin{array}{l}\text { Travel time to } \\
\text { reach an } \\
\text { asphalted road }\end{array}$ & $\begin{array}{l}-0.027 \\
(-1.90)\end{array}$ & $-0.041(-2.71) * * *$ & $-0.019(-0.85)$ & $\begin{array}{c}-0.004 \\
(-0.16)^{*}\end{array}$ & $\begin{array}{c}-0.019 \\
(-2.89)^{* *}\end{array}$ & $\begin{array}{r}-0.020 \\
(-2.44)\end{array}$ & $\begin{array}{l}0.036^{*} \\
(6.81)\end{array}$ & $\begin{array}{c}0.258 \\
(3.87)^{*}\end{array}$ \\
\hline $\begin{array}{l}\text { Area of land } \\
\text { exploited }\end{array}$ & $\begin{array}{c}0.048 \\
(3.18)^{* *}\end{array}$ & $0.040(2.16)^{*}$ & $0.045(1.86)$ & $0.036(1.39)$ & $\begin{array}{c}0.065 \\
(4.59)^{*}\end{array}$ & $\begin{array}{r}\mathbf{0 . 0 1 7} \\
(\mathbf{1 . 0 6}) \\
\end{array}$ & $\begin{array}{r}0.583 \\
(3.86)^{*}\end{array}$ & $\begin{array}{c}0.817 \\
(3.18)^{*}\end{array}$ \\
\hline $\begin{array}{l}\text { Head obtained a } \\
\text { credit }\end{array}$ & $\begin{array}{l}0.201 \\
(3.09)^{* *}\end{array}$ & $0.186(2.88)^{*}$ & $\begin{array}{c}0.147 \\
(1.44)\end{array}$ & $0.267(2.25)$ & $\begin{array}{c}0.173 \\
(3.56)^{*}\end{array}$ & $\begin{array}{c}0.156 \\
(2.98)^{*} \\
*\end{array}$ & $\begin{array}{c}0.108 \\
(5.02)^{*}\end{array}$ & $\begin{array}{c}0.161 \\
(4.32)^{*}\end{array}$ \\
\hline intercept & $\begin{array}{c}13.287 \\
(123.30)^{*}\end{array}$ & $12.775(92.37)$ * & $\begin{array}{c}13.226(79.69) \\
*\end{array}$ & $\begin{array}{c}13.991 \\
(66.19)^{*}\end{array}$ & $\begin{array}{c}12.827 \\
(212.46)^{*}\end{array}$ & $\begin{array}{c}\mathbf{0 . 0 7 8} \\
(155.31 \\
)^{*}\end{array}$ & $\begin{array}{c}-0.037 \\
(-3.44)^{* *}\end{array}$ & $\begin{array}{l}-0.026 \\
(-1.36)\end{array}$ \\
\hline $\begin{array}{c}\text { Number of } \\
\text { observations }\end{array}$ & & 1181 & 1181 & 1181 & 2539 & 3036 & 3036 & 3036 \\
\hline Pseudo-R2 & & 0.277 & 0.255 & 0.293 & & 0.217 & 0.237 & 0.221 \\
\hline
\end{tabular}

Notes: Robust $t$ - statistics are between parentheses.

* Significant at the 1\% level; ** significant at the 5\% level; *** significant at the $10 \%$ level.

Source: Calculations of the author using the data of the Cameroonian household survey Ecam 3 


\subsection{The Results of the Oaxaca-Blinder Decomposition Method}

Table 4 below shows the results derived from the Oaxaca-Blinder decomposition method. The predicted yearly average consumption amounts to 12.632695 CFA Franc for the urban area, and to 12.2703 CFA Franc for the rural area. The overall difference in welfare between the urban and rural areas is estimated at 0.3623905 CFA Franc. The urban-rural welfare difference in Cameroon is decomposed into two components: an explained component of 0.1640441 representing $45 \%$ of the total welfare difference, and the unexplained component of 0.1983464 representing $55 \%$ of the total welfare difference. The explained difference is attributed to differences in household characteristics, while the unexplained difference is due to discrimination or pure bias.

The greatest contributor to the urban-rural welfare difference explained by endowments is the value of the employment sector (service sector) of the household head with a share of $13.57 \%$. The latter is followed by the average time span spent to reach the market place, the average time span spent to reach an asphalted road, and by the characteristics of education (higher education) in the explanation of the urban-rural welfare difference. The characteristics of higher education explain $10.27 \%$ of the urban-rural welfare difference, and the characteristics of second-cycle secondary education explain only $6.71 \%$ of this welfare difference.

Table 4. Oaxaca-Blinder Decomposition of the Welfare Gap Results

\begin{tabular}{|c|c|c|c|c|}
\hline & $\begin{array}{c}\text { Estimate amount attributable } \\
\text { to characteristics (Amount } \\
\text { explained) }\end{array}$ & $\begin{array}{c}\text { Share } \\
\text { (in \%) }\end{array}$ & $\begin{array}{c}\text { Estimate amount attributable } \\
\text { to coefficients } \\
\text { (Amount unexplained) }\end{array}$ & $\begin{array}{l}\text { Share } \\
\text { (in \%) }\end{array}$ \\
\hline Douala & $-0,008352$ & $-2,31$ & 0 & 0,00 \\
\hline Adamaoua & 0,0016914 & 0,47 & $-0,00755$ & $-2,08$ \\
\hline centre & 0,0130303 & 3,60 & $-0,03486$ & $-9,62$ \\
\hline East & $-0,000166$ & $-0,05$ & $-0,00945$ & $-2,61$ \\
\hline Extreme-North & 0,0125014 & 3,45 & 0,007212 & 1,99 \\
\hline littoral & $-0,041907$ & $-11,58$ & $-0,02781$ & $-7,67$ \\
\hline North & 0,0003008 & 0,08 & 0,003848 & 1,06 \\
\hline Northwest & $-0,005287$ & $-1,46$ & $-0,03705$ & $-10,22$ \\
\hline West & 0,0119639 & 3,30 & $-0,06901$ & $-19,04$ \\
\hline South & $-0,003465$ & $-0,96$ & $-0,01914$ & $-5,28$ \\
\hline Southwest & 0,0000148 & 0,00 & $-0,01823$ & $-5,03$ \\
\hline household size & $-0,066235$ & $-18,30$ & 0,032837 & 9,06 \\
\hline female & 0,0009726 & 0,27 & 0,003082 & 0,85 \\
\hline household head has a spouse & $-0,008279$ & $-2,29$ & $-0,00917$ & $-2,53$ \\
\hline Age of head of household: $30-39$ years old & $-0,000514$ & $-0,14$ & $-0,00014$ & $-0,04$ \\
\hline Age of head of household: $50-59$ years old & $-0,009302$ & $-2,57$ & 0,004274 & 1,18 \\
\hline Age of head of household: 60 years or older & 0,0010597 & 0,29 & 0,022808 & 6,29 \\
\hline Level of Head's edu: primary & $-0,002724$ & $-0,75$ & $-0,00213$ & $-0,59$ \\
\hline Level of Head's edu: secondary 1rst cycle & 0,0102595 & 2,83 & 0,007368 & 2,03 \\
\hline Level of Head's edu: secondary 2nd cycle & 0,024297 & 6,71 & 0,005087 & 1,40 \\
\hline Level of Head's edu: higher & 0,0371596 & 10,27 & 0,003892 & 1,07 \\
\hline Industrial sector & 0,0013218 & 0,37 & $-0,00331$ & $-0,91$ \\
\hline Trade sector & 0,0187858 & 5,19 & 0,001327 & 0,37 \\
\hline Services sector & 0,0491227 & 13,57 & 0,012502 & 3,45 \\
\hline Executives & 0,0236346 & 6,53 & $-0,00018$ & $-0,05$ \\
\hline skilled employees & 0,0057366 & 1,58 & $-0,00187$ & $-0,52$ \\
\hline unskilled workers & $-0,003331$ & $-0,92$ & $-0,00113$ & $-0,31$ \\
\hline managers (bosses) & $-0,000729$ & $-0,20$ & 0,002767 & 0,76 \\
\hline Is a member of an association & 0,0157965 & 4,36 & 0,006973 & 1,92 \\
\hline Travel time to market place & 0,0417189 & 11,52 & $-0,09864$ & $-27,22$ \\
\hline Travel time to reach an asphalted road & 0,041718 & 11,52 & $-0,02646$ & $-7,30$ \\
\hline Area of land exploited & $-0,00017$ & $-0,05$ & $-0,01056$ & $-2,91$ \\
\hline Head obtained a credit & 0,0047081 & 1.30 & 0,001125 & 0,31 \\
\hline intercept & 0 & 0,00 & 0,459925 & 126,91 \\
\hline Total & 0,1653328 & $45,67 \%$ & 0,198346 & $54,73 \%$ \\
\hline
\end{tabular}

Source: Calculations of the author using the data of the Cameroonian household surveys Ecam 3

$\underline{\mathrm{NB}}$ : Share is a ratio of the contribution of each factor to the "predicted" overall difference in welfare in percentage terms 
The results also show that the effects of the coefficients of second-cycle secondary education and higher education are quite small, while the effects of characteristics are substantial. This fact underlines the importance of obtaining higher educational levels for household members, for it is the gap in the level of education achieved by urban and rural households that turns out to be one of the major causes of welfare differences.

The results of the explained component indicate that variables such as the area of cultivated lands, being an unskilled worker, being a manager (or the boss), primary education, the 50-59 age group, the 60-and-more age group, having a spouse, and household size favour rural households, while the gap in the rest of the variables put rural households at a disadvantage. On the other hand, the constant term acts to increase the welfare gap, thus reflecting the underlying differences between the two groups which are not captured by the other explanatory variables.

The main factors creating the welfare bias against the rural area are household size followed the 60 -and-more age group, both of which respectively explain $9.06 \%$ and $6.29 \%$ of the discrimination.

The negative coefficient differentials of the regional dummy variables indicate that, on the average, the marginal benefits of rural households that are located in regions different from the reference region tend to be higher than the marginal benefits of the urban households that are not located in the reference region, while controlling for other factors.

\section{Conclusion and Policy Implications}

The overall objective of this study was to identify the determinants of income and the urban-rural income gap in Cameroon in 2007, using the data stemming from the 2007-Cameroonian household survey ECAM3. This objective has been achieved in two stages: firstly by identifying the determinants of welfare in the urban and rural areas using OLS regressions and quantile regressions and secondly, by decomposing welfare inequality into the relative contributions of endowments and discrimination using the Oaxaca-Blinder $[25,26]$; decomposition method.

The results of the study show that among all the individual characteristics, the type of occupation and education are the two most influential factors that determine the welfare level of households. The household heads who work in the non-agricultural sectors of the economy, particularly those working in the industrial, trade and services sectors enjoy higher consumption expenditure levels than those who work in the agricultural sector, both in the rural and urban areas. Similarly, households whose heads are managers or qualified employees have higher consumption expenditure levels than those of the household heads who are self-employed or apprentices in the urban and rural areas.

There exists a positive relationship between education and the consumption expenditures of urban and rural households.
The gender income gap is evident in the 2007-ECAM3 household survey which shows that men have higher expenditure levels than women in Cameroon. The age groups of household heads, their matrimonial statuses and household size exert negative impacts on the consumption expenditures of households both in the urban and rural areas. The study also finds that access to credit to get involved in business and agriculture or to become a member of any association, increases the welfare of rural and urban households. Finally, the results of the study show that the lack of infrastructures in the rural area contributes significantly to the exclusion of certain households from the markets and from income-generating opportunities, a situation that may reduce the welfare of the rural population.

Quantile regressions capture the non-uniform effects of individual characteristics at different quantiles of the household consumption expenditure distribution. It is particularly remarkable that for urban and rural households, first and second cycles secondary education is beneficial to the poor. On the other hand, higher education significantly improves the welfare of rich households in both the urban and rural areas.

The results of both the urban and rural households show that household heads employed in trade improve the welfare of households for all the quantiles of the distribution of welfare. On the other hand, household heads employed in the industrial sector of the economy improve the welfare of the average rich and of the rich in the urban area as well as the welfare of all the quantiles of household expenditures in the rural area. Household heads who work in the industrial sector decrease the consumption expenditures of the poor in the rural area.

The fact that household heads work in the industrial sector of the economy improves the welfare of the average rich and the rich in the urban area, as well as the welfare of the rich, average rich and the poor in the rural area. The fact that households work in the services sector improves the consumption expenditures of the average rich and the rich, and decreases the consumption expenditures of the poor in the rural area. The household heads who are unqualified workers are poor for all the quantiles of the expenditure distribution in the urban area, and at the $10^{\text {th }}$ quantile in the rural area. On the other hand, the household heads who are unqualified workers tend to be rich in the rural area.

The results derived from the Oaxaca-Blinder decomposition method indicate the existence of a welfare gap between the urban and rural areas. This is largely explained by the differences in characteristics, and particularly by physical assets and education at the rate of $59 \%$. The remaining $41 \%$ of the welfare gap is attributable to discrimination.

The results presented in this study have several implications for the conception of strategies for the reduction of poverty and urban-rural welfare inequality. The first policy implication relates to the importance of human and physical capital endowments in the determination of welfare in Cameroon. The importance of education both for urban 
and rural households cannot be overemphasized, since education represents an important tool that may be used to reduce poverty and urban-rural welfare inequality.

The study also indicates the importance of smaller-sized households to ensure higher welfare levels. The fertility rate of five or six children per woman in Cameroon should be urgently reduced, since a lower fertility rate would reduce the dependence ratio.

One of the main sources of welfare differences between urban and rural households resides in the endowments of market characteristics. Consequently, policies aimed at the reduction of the urban-rural income gap should include education and employment opportunities. The creation of opportunities for paid employment can be achieved by increasing agricultural productivity among the farmers and self-employment opportunities. Microfinance is particularly relevant for boosting productivity and self-employment in the informal sector of the economy. It would make it possible for farmers to buy the inputs they need to increase their productivity as well as to finance a range of activities likely to increase the value of agricultural output and to develop the rural non-agricultural economy. Development policies that increase the returns of characteristics may promote the urban-rural link and the reduction of poverty and inequality. More specifically, the urban-rural disparity may be better addressed by raising labour-market flexibility and investment in rural area infrastructures. This would help to orient the flow of goods, services and labour towards the regions that provide the best results.

\section{Acknowledgements}

This study is inspired by research supported by African Economic Research Consortium (AERC). I wish to express my deep appreciation to AERC for the financial support to carry out this research. I am also grateful to the resource persons and members of AERC's thematic group A for various comments and suggestions that helped the evolution of this study from its inception to completion. I am indebted to the anonymous referees who reviewed the paper and provided comments and suggestions that helped in shaping and improving the overall quality of the paper. The findings made and opinions expressed in this paper are exclusively those of the author. The author is also solely responsible for content and any errors.

The early draft of this paper was presented in 2014 CSAE Conference: "Economic Development in Africa", held at St Catherine's College, Oxford 23rd - 25th March 2014. I would also like to thank participants of this Conference for their comments.

\section{REFERENCES}

[1] African Development Bank (AfDB), (2012). Briefing Note 5: Income Inequality in Africa. March.
[2] Adugna, T., and Heidhues, v., (2000). Determinants of Farm Households access to Informal Credit in Lume District, Central Ethiopia. Savings and Development, Vol.24, No.4, 27 -46 .

[3] Ali, L., R., Ramay, M., I., and Nas, Z., (2013). Analysis of the determinants of income and income gap between urban and rural Pakistan. Interdisciplinary Journal of Contemporary Research in Business, Vol. 5, No.1, 858-885.

[4] Anyanwu, J. C. (2010), "Poverty in Nigeria: A Gendered Analysis", African Statistical Journal, Vol. 11, 38-61.

[5] Anyanwu, J. C. (2005), "Rural Poverty in Nigeria: Profile, Determinants and Exit Paths", African Development Review, Vol. 17, No. 3, 435-460.

[6] Barros, R., Fox, L. and Mendonca, R. (1997) Female Headed Households, Poverty, and the Welfare of Children in Urban Brazil. Economic Development and Cultural Change, Vol. 45 No.2, 231 - 57.

[7] Baye Menjo, F. and Fambon, S. (2002). Decomposition of inequality in the distribution of living standards in Cameroon. African journal of Economic Policy, Vol. 9, No.2.

[8] Blackorby, C., and D. Donaldson. (1988). Money Metric Utility; a harmless normalization? Journal of Economic Theory, Vol. 46, 120-29.

[9] Binswanger, H. P and S. R. Khandker. (1995). The Impact of Formal Finance on the Rural Economy of India. Journal of Development Studies, Vol.32, No.2, 234 - 262.

[10] Blinder, A.S., (1973). Wage discrimination: reduced form and structural estimates, Journal of Human Resources, Vol.8, 436-455.

[11] Canagarajah, S. and Claus C. Portner, C., C., (2003).Evolution of Poverty and Welfare in Ghana in the 1990s: Achievements and Challenges", the World Bank, African Region Working Paper Series, No.61.

[12] Chamarbagwala, R., (2010). "Economic Liberalization and Urban-Rural Inequality in India: a Quantile Regression Analysis”, Empirical Economics, Vol. 39, 371-394.

[13] Chameni Nembua, C. and Miamo Wendji, C., (2012). Inequality of Cameroonian Households: An Analysis Based on Shapley-shorrocks Decomposition International Journal of Economics and Finance, Vol. 4, No.6, 149-156.

[14] Cleaver, M. K. (1993) A Strategy to Develop Agriculture in SSA and a focus for the World Bank, World Bank Technical Paper No 203, Africa Technical Department Series.

[15] Cortes, F. (1997), "Determinants of Poverty in Hogares, Mexico, 1992", Revista Mexicana de Sociologia, Vol. 59, No. $2,131-160$.

[16] Datt, G., Simler, K., S. Mukherjee and G. Dava (2000). Determinants of Poverty in Mozambique: 1996-97, International Food Policy Research Institute (IFPRI), Food Consumption and Nutrition Division (FCND), Discussion Paper No. 78.

[17] Datt, G., Jolliffe, D., and Sharma, M., (2001). A profile of poverty in Egypt. African Development Review Vol.13, No.2, 202-237.

[18] Datt, G. and Jolliffe, D. (1999). Determinants of Poverty in Egypt: 1997, FCND Discussion Paper No. 75, October. 
[19] Deaton, A., and Zaidi, S., (2002). Guidelines for Constructing Consumption Aggregates for Welfare Analysis, Living Standards Measurement Study (LSMS), Working Paper No. 135, World Bank, Washington DC.

[20] Deaton, A and Paxson, C. (1998). "Economies of scale, household size, and the demand for food." Journal of Political Economy Vol.106, No.5, 897-930.

[21] Deaton, A. (1997). The Analysis of Household Survey: A Microeconometric Approach to Development Policy. Washington, DC: World Bank.

[22] Fambon, S. (2010). Inequality in the distribution of household expenditure in Cameroon: AGini decomposition analysis based on the Shapley-value approach. Educational Research, vol.1, No.2, 021-031.

[23] Fields, G. S. (1980). Poverty, Inequality and Development, Cambridge University Press.

[24] Fields, G.S. (1997). Accounting for Income Inequality and its Change, Paper presented at the American Economic Association annual meeting, New Orleans.

[25] Gang, I. N., Sen, K., and Yun, M., S., (2004), Caste, Ethnicity and Poverty in Rural India. (See: www.wm.edu/economics/seminar/papers/gang.pdf)

[26] Geda, A., Shimeles, A., and Zerfu, D. (2006). Finance and Poverty in Ethiopia: A household level analysis, United Nations University (UNU) - World Institute for Development Economics Research (WIDER), Research Paper No. 2006/51

[27] Glewwe, P. (1986). The distribution of Income in Sri Lanka in 1969 to 70 and 1980 to 81 : A decomposition analysis, Journal of Development Economics, Vol. 24, 255-274.

[28] Institut National de la Statistique (INS) (2007), Troisième Enquête Camerounaise auprès des ménages ECAM3, Yaoundé.

[29] Kakwani, N. (1980). Income Inequality and Poverty: Methods of Estimation and Policy Implications, Oxford: Oxford University Press.

[30] Kanbur, R.,Loprz-Calva, L. , and Venables, A. (2005). "Symposium of Spatial Inequality in Latin America", Cuadernos de Economía Vol.42, 133-136.

[31] Koenker, R. and Bassett,G., Jr., (1978) 'Regression Quantiles,' Econometrica, Vol.46, No.1,33-50.

[32] Lanjow, P. and Ravallion, M. (1995) Poverty and Household Size, the Economic Journal, Vol.105, 1415 - 1434.

[33] Lipton, M. and Ravallion, M. (1995) Poverty and Policy, in J. Behrman and T. N. Srinivasas (eds.), Handbook of Development Economics, Volume 3, Oxford, Elservier Science, North Holland.

[34] Litchfield, J. A. (1999) Inequality: Method and tools, The World Bank, Washington DC.

[35] Machado, J. A. F and J. Mata (2005) Counterfactual Decomposition of Changes in Wage Distributions using Quantile Regression, Journal of Applied Econometrics, Vol.20, No.4, 445-465.

[36] Matita, M., M., and Chirwa, E.,W., (2009). Rural - Urban Welfare Inequalities in Malawi: Evidence from a Decomposition Analysis. University of Malawi Chancellor
College, Department of Economics, Working Paper No. 2009/05.

[37] Minot, N. and Baulch, B. , (2004). "The Spatial Distribution of Poverty in Vietnam and the Potential for Targeting", in Glewwe, P., Agrawal, N., and Dollar, D., eds. (2004) Economic Growth, Poverty, and Household Welfare in Vietnam, Washington, D.C.: World Bank.

[38] Mukherjee, S., and Benson, T., (2003). The Determinants of Poverty in Malawi, 1998, World Development, Vol. 31 No. 2, $339-358$

[39] Ngah Epo, B. and Menjo Baye, F. (2013). Determinants of Inequality in Cameroon: A Regression-Based Decomposition Analysis. Botswana Journal of Economics, Vol 11, No 15, $2-20$.

[40] Nguyen, B.T., Albrecht, J. W., Vroman, S. B., and Westbrook, M. D., (2007). A Quantile Regression Decomposition of Urban-Rural Inequality in Vietnam, Journal of Development Economics Vol. 83, 466-490.

[41] Oaxaca, R., (1973). Male-female wage differentials in urban labor markets, International Economic Review, Vol. 14, 693-709.

[42] Ravallion, M., (1998). Poverty lines in theory and practice. Living Standards Measurement Study Working Paper No. 133. Washington, D.C.: World Bank.

[43] Rodriguez, J. G. (2002). The Determinants of Poverty in Mexico, (see www.gdnet.org/pdf/2002AwardsWinners/GrowthInequalityP overty/Jorge_garza_rodriguez_paper.pdf).

[44] Sen, A. (1973). On Economic Inequality, Oxford: Oxford University Press.

[45] Shipi, F. (2008). Migration, Sorting and Regional Inequality: Evidence from Bangladesh, World Bank Policy Research Working Paper No. 4616.

[46] Shorrocks, A. F. (1984). Inequality Decomposition by Population Subgroups, Econometrica, Vol. $52 \mathrm{~N}^{\mathrm{o}} 6,1369-85$.

[47] Sicular, T., Yue, X.M., Gustafasson, B., and Li, S. (2007). The Urban-Rural Income Gap and Inequality in China. Review of Income and Wealth Vol. 53, No. 1, 93-126.

[48] Su, B. and Heshmati, A., (2013). Analysis of the Determinants of Income and Income Gap between Urban and Rural China. IZA DP No. 7162

[49] Theil, H. (1979). Economics and Information Theory, Amsterdam: North Holland.

[50] Wodon, Q., (1999). Microdeterminants of Consumption, Poverty, Growth and Inequality in Bangladesh. Policy Research Working Paper 2076, World Bank.

[51] World Bank (2006). World Development Report 2006: Equity and Development. New York, Oxford: Oxford University Press.

[52] World Bank (1991). Gender and Poverty in India. The World Bank, Washington.

[53] Zeller, M., Braun J.V., Johm, K. and Puetz, D. (1994). Sources and Terms of Credit for the Rural Poor in the Gambia. Africa Review of Money Finance and Banking, Vol.1, 167-186 